\title{
Formation of the competencies of future teacher-speech therapists in the field of intercultural communication
}

\author{
Galina Butko ${ }^{*}$, Gulnara Shashkina ${ }^{1}$, and Nina Drozdova $^{2}$ \\ ${ }^{1}$ Moscow City University, Department of Speech Therapy, Moscow, Russia \\ ${ }^{2}$ Belarusian State Pedagogical University named after Maxim Tank, Institute of Inclusive Education, \\ Department of Speech Therapy, Minsk, Belarus
}

\begin{abstract}
This article discusses topical issues of future speech therapists' training in terms of a competence approach. Special attention is paid to formation of universal competences of future teachers in the field of intercultural collaboration. Current bachelor training curricula of specialized (speech pathology) education of speech therapy major 44.03 .03 have been analyzed regarding formation of competences of future speech therapists in the field of intercultural communication. Efficient intercultural communication does not emerge spontaneously, it should be consistently developed. Modern life calls for mastering the skills of such communication. At present, special attention is paid to formation of universal competences in future speech pathologists, especially aimed at intercultural collaboration. It is believed that a speech therapist possessing such competences will be able to perceive cultural diversity of society in social, historical, and philosophical contexts. This article analyzes the experimental study of development level of future speech therapists' general cultural competences. Junior and senior students from the Department of speech therapy, Institute of special education and psychology, Moscow City University took part in this research. The main experimental method was a survey of students. Particular attention was paid to the issues of formation of speech culture of speech therapists and the possibility to apply knowledge acquired during studies of a humanitarian module in professional activities of cultural and educational type. The main results of the analysis are a proven opportunity of updating theoretical knowledge of speech therapists in the field of intercultural communication acquired during studies of humanitarian, psychological, pedagogical and professional sections using interactive approaches to teacher activities.
\end{abstract}

Keywords: speech pathologist, inclusive processes, general cultural competences, intercultural collaboration.

*Corresponding author: butkoga@mgpu.ru 


\section{Introduction}

The scientific term of "intercultural communication" emerged in publications in the second half of the twentieth century; however, historical roots of intercultural communication could be found in the faraway past of mankind. The most meaningful manifestations of intercultural communication are familiar to each schoolchild: for instance, the rise and fall of ancient civilizations, formation of various religions, great geographical discoveries, colonization of vast territories by developed countries, and fall of the colonial system [1].

Modern processes of globalization, reflected in closer political, economic, and cultural interactions among various countries and nations make the issue of intercultural communication an object of interest to experts of various scientific areas [2]. Nowadays intercultural communication is understood in a broad sense as an interrelation and collaboration between various cultures and nations of the world, which is expressed not only through direct contacts among people and communities, but also through indirect forms of communication, such as language, speech, writing, digital communication, etc. [3]

Intercultural communication is studied at an interdisciplinary level, including psychology and pedagogics. Particular attention is paid to education of the rising generation possessing the major skills of intercultural communication, capable of understanding and accepting cultural diversity of modern humankind. Formation of intercultural competence is one of the major targets of modern education [4].

Issues of interacting with differently abled people are a special focus of modern society. In Russia and other countries, which chose inclusion in their educational systems, social life is being modified to fully meet demands of each member of society, including people with health and social functioning limitations [5]. Under such conditions development of skills and habits of intercultural collaboration by all participants in the inclusion process is vital $[6]$.

The changes in the education system drive reinterpretation of a speech therapist's role under the conditions of significant distribution of inclusive practice and creation of a tolerant environment in educational institutions [7]. That is why the preparation of teachers for the inclusion process is widely discussed both by teachers and parents, and at a governmental level [8].

Among the challenges of training speech therapists, the issue of identifying required and sufficient competences definitely stands out. After completing the bachelor's program, a graduate should possess universal, general and specific professional competences [9].

Currently the issues of a competence approach in speech therapists' training are widely discussed by leading experts: I.Yu. Levchenko, N.M. Nazarova, I.M. Yakovleva, M.V. Zhigoreva [10]. However, the issue of forming universal competences is so broad that the results of these studies do not fully comprise the whole range of problems related to the competences of intercultural collaboration.

\section{Methods}

To analyse the general cultural competence development level of future speech therapists the authors carried out experimental research among 3rd and 4th year students from the Department of speech therapy, Institute of special education and psychology, Moscow City University. 128 full-time (FT) and half-time (HT) students participated in the experiments, there were 85 full-time students and 43 half-time students. The research was conducted in two stages. The first stage was devoted to surveying the main issue of intercultural collaboration. The survey was carried out during practical classes.

The second stage included watching a movie about integrating a bilingual child into the educational environment of school No. 518, Moscow. After watching the movie the 
students answered five questions about their attitude to interpersonal collaboration among the children and the environment of the school enrolling bilingual and nonnative (inophone) speakers.

\section{Results}

Table 1. Survey results of FT and HT students, $\%$.

\begin{tabular}{|c|c|c|c|c|}
\hline \multirow{2}{*}{ Survey section } & \multicolumn{2}{|c|}{ FT students (85-100\%) } & \multicolumn{2}{c|}{ HT students (43-100\%) } \\
\cline { 2 - 5 } & High level & Medium level & High level & Medium level \\
\hline $\begin{array}{c}\text { Theoretical foundations of } \\
\text { Speech Therapy and its } \\
\text { connection with other } \\
\text { sciences }\end{array}$ & $\mathbf{9 1 . 7 6}$ & 8.24 & $\mathbf{8 1 . 3 9}$ & 18.61 \\
\hline $\begin{array}{c}\text { Regularities of normal } \\
\text { speech development }\end{array}$ & $\mathbf{7 8 . 8 2}$ & 21.17 & $\mathbf{7 6 . 7 4}$ & 23.26 \\
\hline $\begin{array}{c}\text { Speech culture of speech } \\
\text { therapist }\end{array}$ & $\mathbf{8 8 . 2 4}$ & 11.76 & $\mathbf{6 5 . 1 2}$ & 34.88 \\
\hline Average score & $\mathbf{8 6 . 2 7}$ & 13.72 & $\mathbf{7 4 . 4 1}$ & 25.58 \\
\hline
\end{tabular}

The survey analysis demonstrated that the section of questions concerning speech culture of a speech therapist was successful for many students participating in the survey. Almost all the students understand the importance of speech culture of a special educator, are able to distinguish impaired and dialect pronunciation as well as to understand that a speech therapist is a teacher directly working with the norms of modern Russian standard language. The percentage of successful answers to the questions of this section are slightly different for FT and HT students $(88.24 \%$ to $65.12 \%)$. Among the HT students, there are bilingual students, simultaneously speaking two mother tongues. Herewith, they speak Russian only in university and at work.

Table 2. Analysis of movie watching by FT and HT students, \%.

\begin{tabular}{|l|c|c|c|c|}
\hline \multirow{2}{*}{ Sections of study } & \multicolumn{2}{|c|}{ FT students (85-100\%) } & \multicolumn{2}{c|}{ HT students (43-100\%) } \\
\cline { 2 - 5 } & High level & Medium level & High level & Medium level \\
\hline Child speech errors & $\mathbf{8 3 . 5 3}$ & 16.47 & $\mathbf{5 3 . 4 9}$ & 46.51 \\
\hline $\begin{array}{l}\text { Features of their } \\
\text { involvement in class } \\
\text { activities }\end{array}$ & $\mathbf{8 8 . 2 4}$ & 11.76 & $\mathbf{8 8 . 3 7}$ & 11.63 \\
\hline $\begin{array}{l}\text { Attitude of parents to } \\
\text { successes and failures of } \\
\text { child }\end{array}$ & $\mathbf{7 7 . 6 4}$ & 22.36 & $\mathbf{8 8 . 7 2}$ & 11.28 \\
\hline $\begin{array}{l}\text { Capabilities of child to } \\
\text { study the Russian } \\
\text { language }\end{array}$ & $\mathbf{8 0 . 0 0}$ & 20.00 & $\mathbf{7 9 . 0 7}$ & 20.93 \\
\hline Average score & $\mathbf{8 2 . 3 5}$ & 17.65 & $\mathbf{7 7 . 4 1}$ & 22.58 \\
\hline
\end{tabular}

Analysis of watching a movie demonstrated that the FT students had more thorough knowledge about adaptation of a child to school in comparison with the HT students. Probably, this could be attributed to the fact that in the case of FT, more attention was paid to mastering general cultural disciplines (difference in class hours). Analysis of other survey sections demonstrated that the students understood the importance of a child's involvement in class activities both during classes and extramural activities (walking, excursions, fests). The students also mention the highest importance of objective parental attitude to different child's marks in the Russian language and the influence of family on learning abilities. 


\section{Discussion}

In order to update theoretical knowledge of students majoring in Speech Therapy the Department of Speech Therapy, Moscow City University prepared working programs for disciplines and modules in accordance with the curriculum for bachelors' training. All the working programs were developed on the basis of the Approximate basic curriculum for bachelors' training with consideration of professional standards in combination with professional activities of a graduate [11].

The disciplines of integrated modules are vital to formation of competences in the field of intercultural communication, in humanities in particular, which are basic for the professional module. The curriculum includes the following disciplines: Cultural Codes, Thinking and Writing, Great Books. Introduction of these disciplines has enabled an expansion of the students' knowledge concerning the issue of intercultural communication. It has assisted in understanding numerous aspects of human collaboration by means of the main constituents of this process: culture and language [12].

Cultural Codes discipline forms concepts of an information semiotic approach to culture, main types of sign systems of culture. The cultural code is considered a system of signs, senses and their combination, contained in any object of a material and spiritual human activity; a method of storage and transfer of information: cultural memory [13]. After completion of the disciplines, the students acquire the competences of intercultural collaboration, based mainly on understanding the role of a culture in this process.

While studying the Thinking and Writing discipline, the students acquire presentations of language norms and thinking under conditions of a variety of social strategies and ethnic cultures of modern society. The first place is given to the tasks of consistently mastering a combination of professionally oriented intercultural communicative competences; formation of competences relevant to actual communications.

The Great Books discipline added to the curriculum enables students to understand the value of global literature heritage aiming at forming their own worldview as well as professional development. While studying the universal competences are formed, such as an ability to search, to run a critical analysis and synthesis of information contained in great masterpieces, to produce various communications in oral and written forms resorting to the patterns contained in works of Russian and foreign writers.

The psychological and pedagogical module includes the discipline titled: Technology of professional communication and teacher acting skills, describing the issues of professional communication as well as ethics of human contacts, empathy and sympathy in communications. Particular attention is paid to the moral culture of pedagogical communication and its formation, pedagogical tact is fostered as a component of the spiritual culture of a speech therapist [14].

An interesting opportunity to expand knowledge in the field of collaboration of various cultures is the choice of this topic from a wide range of general university elective classes. Thus, the elective class "East and West: Dialogue and Collaboration" forms concepts of philosophy of a European and Oriental person. In addition, this class touches upon a very complex issue of the modern world: an interreligious dialogue and an interreligious collaboration in terms of historic retrospective, current, and future forecasts. Such diverse and universal literacy of a speech therapist would enable them to take a proper place in modern education models as well as to be required in other meaningful areas of human life.

\section{Conclusion}

Therefore, while teaching Bachelor's students (Speech therapy), close attention is paid to developing universal competences in the field of intercultural communication, since they 
are the base of efficient professional activities. The achievement of the laid forward targets is enabled by introduction of new humanities into the curriculum as well as an analysis of vital aspects of intercultural communication in disciplines of professional section, a possibility to choose relevant general university elective classes, innovation forms of lecture development and practical classes [15]. The applied efforts result in shaping a new type of a speech therapist possessing intercultural sensitivity; the one recognizing the issue of collaboration with representatives of other cultures and having cultural and communication convictions, which can influence people behavior during intercultural collaboration.

\section{References}

1. R. Scollon, S. Wong Scollon, R.H. Jones, Intercultural Communication: A Discourse Approach (Wiley-Blackwell, New York, 2012)

2. N.S. Safayev, Herald of Omsk University. Series: Psychology, 2, 25-28 (2018). https://doi.org/10.25513/2410-6364.2018.2.25-28

3. I.A. Postoenko, Uchenyie zametki TOGU, 8(1(2)), 222-226 (2017). Accessed on: December 16, 2020. [Online]. Available: http://pnu.edu.ru/media/ejournal/articles2017/TGU_8_95_1.pdf

4. I. Froumin, I. Remorenko, From the "Best-in-the World" Soviet School to a Modern Globally Competitive School System, in Audacious Education Purposes How Governments Transform the Goals of Education Systems, 233-250 (Springer, Cham, 2020). https://doi.org/10.1007/978-3-030-41882-3_9

5. G.A. Butko, T.A. Katelson, S.P. Oltu, Vestnik Mininskogo Universiteta, 7(4(29)), 5 (2019). https://doi.org/10.26795/2307-1281-2019-7-4-5

6. G.R. Shashkina, "Plyusy" $i$ "minusy" inklyuzivnogo obrazovaniya $v$ obshcheorazovatelnoy shkole ["Pros" and "cons" of inclusive education in secondary schools], in Proceedings of the conference "Rebenok s ogranichennymi vozmozhnostyami zdorov'ya v yedinom obrazovatel'nom prostranstve: spetsial'noye i inklyuzivnoye obrazovaniye", 19-20 December, Moscow, Russia, 80-86 (2014)

7. I.A. Novikova, Psikhologiya Obrazovaniya v Polikul'turnom Prostranstve, 1(29), 52 $62(2015)$

8. L.Y. Vakorina, O.G. Prikhodko, O.V. Yugova, RUDN Journal of Sociology, 19(4), 814-824 (2019). https://doi.org/10.22363/2313-2272-2019-19-4-814-824

9. D.L. Agranat, Vestnik Moskovskogo Gorodskogo Pedagogicheskogo Universiteta. Seriya: Pedagogika i Psikhologiya, 2 (52), 8-13 (2020). https://doi.org/10.25688/20769121.2020.52.2.01

10. I.Y. Levchenko, Y.V. Logunova, T.V. Skrebets, Vestnik Mininskogo Universiteta 7(3(28)), 11 (2019). https://doi.org/10.26795/2307-1281-2019-7-3-11

11. I.Y. Levchenko, Kompetentsii sovremennogo spetsialista $v$ oblasti raboty s det'mi s tyazhelymi mnozhestvennymi narusheniyami razvitiya [Competencies of a modern specialist in the field of working with children with severe multiple developmental disabilities], in Proceedings of the Fourth International Scientific and Practical Conference "Evolyutsiya slepoglukhoty i chto iz etogo sleduyet", 3-4 April 2018, Moscow, Russia (2018)

12. N.V. Serebryakova, G.R. Shashkina, Problemy sovremennogo pedagogicheskogo obrazovaniya, 67(4), 341-345 (2020) 
13. L.A. Samovar, R.E. Porter, E.R. McDaniel, C.S. Roy, Communication Between Cultures (Cengage Learning, Wadsworth, 2013)

14. K.I. Roshchina, O.A. Motovilina, Sotsiokul'turnyy kontekst i kinesicheskiye osobennosti neverbal'noy mezhkul'turnoy kommunikatsii [Sociocultural context and kinesic features of nonverbal intercultural communication], in Proceedings of the Conference Aktual'nyye voprosy sovremennoy nauki i obrazovaniya, Borisoglebsk Branch of the Voronezh State University, 2-27 April 2018, Borisoglebsk, Russia, 234241 (2018)

15. D.L. Agranat, A.S. Lvova, O.A. Lyubchenko, Vestnik Moskovskogo Gorodskogo Pedagogicheskogo Universiteta. Seriya: Pedagogika i Psikhologiya, 3(41), 26-36 (2017) 